\title{
INADMISSIBILITY OF WIRETAP EVIDENCE IN STATE COURTS
}

The Supreme Court, in Lee v. Florida,' extended its interpretation of section 605 of the Federal Communications Act $^{2}$ to render conversations intercepted and divulged in violation of the Act inadmissible as evidence in a state court. ${ }^{3}$ Two days after the decision in Lee, the Omnibus Crime Control and Safe Streets Act of $1968^{4}$ became law. The Act rewrote section 605 and added a new chapter to the U.S. Code defining the areas and establishing the procedures for permissible wiretapping. ${ }^{5}$ Lee and the cases which preceded it, ${ }^{6}$ along with the Crime Control Act, comprise the foundation for future developments in the wiretapping area.

Lee ordered a private telephone installed in his house but was able to obtain only a four-party line. Thereafter, the Orlando city police had a phone in a neighboring house connected to the same party line and installed equipment enabling them to hear and record all conversations on the party line. The device was used on calls to and from Lee's residence for more than a week. Lee and two others were convicted of violating the state lottery laws at a trial in which the recorded conversations were admitted in evidence over objection. After the convictions were affirmed by a Florida district court of appeal, ${ }^{7}$ and the Supreme Court of Florida denied further review, ${ }^{8}$ the United States Supreme Court reversed the convictions on a writ of certiorari. ${ }^{9}$

The problem of wiretapping was first considered by the Supreme Court in Olmstead $v$. United States ${ }^{10}$ at a time when no federal legislation covered the subject. In Olmstead, the Court held that

' 392 U.S. 378 (1968).

248 Stat. 1103 (1934), as amended, 47 U.S.C. $\S 605$ (1968 U.S. CODE CoNG. \& AD. NEWS 1525).

${ }^{3} 392$ U.S. at 380 .

‘ 82 Stat. 197 (1968) (1968 U.S. CODE Cong. \& Ad. News 1495) [hereinafter cited as Crime Control Act].

"Id. at (U.S. Code CoNG. \& Ad. News at 1512).

${ }^{\circ}$ See notes 10-24 infra.

'191 So. 2d 84 (Fla. App. 1966).

'196 So. 2d 927 (Fla. 1967).

${ }^{9} 392$ U.S. at 378.

10 277 U.S. 438 (1927). 
evidence obtained by a wiretap in violation of a state statute was admissible, reasoning that telephone conversations were not subject to the fourth amendment's prohibition against unreasonable search and seizure." Since the enactment of section 605 in 1934, the Supreme Court has been continually called upon to determine what Congress intended in enacting the statute. In Nardone v. United States ${ }^{12}$ the Court interpreted section 605 as being comprehensive in its coverage, excluding from the federal courts all evidence obtained by federal officers in violation of the section. Concluding that Congress had not intended to exempt federal officers from the Act, the Court strictly applied the prohibitive terms of section $605 . .^{13}$ Subsequently, in Schwartz v. Texas ${ }^{14}$ the Court ruled that the section 605 prohibitions were not based upon constitutional grounds, and that state courts could admit conversations seized in violation of section 605 which, if seized by federal officers, would be inadmissible in federal courts. ${ }^{15}$ Noting the penal sanctions of the Federal Communications Act ${ }^{16}$ and the view that traditional state regulation should not be supplanted unless the federal statute clearly so provides, ${ }^{17}$ the Court held that a "rule of evidence" would not be imposed on the states. ${ }^{18}$ The more recent case of Benanti v. United States, ${ }^{19}$ however, held that evidence seized in violation of section 605 was inadmissible in a federal court even if seized solely by state officers. ${ }^{20}$ Furthermore, in 1967 the Court interjected the constitutional guarantees of the fourth amendment into the eavesdropping and wiretapping area with the Berger $v$. New York $^{21}$ and Katz v. United States ${ }^{22}$ decisions. Berger heId

\footnotetext{
"Id. at 464-65.

12302 U.S. 379 (1937).

${ }^{13}$ Id. at 382-83; cf. Nardone v. United States, 308 U.S. 338, 339 (1939); Silverthorne Lumber Co. v. United States, 251 U.S. 385, $391-92$ (1920). See also Weiss v. United States, 308 U.S. 321,329 (1939).

" 344 U.S. 199 (1952).

is Id. at $201-03$.

${ }^{16} 47$ U.S.C. $\$ 501$ (1964).

"T See Irvine v. California, 347 U.S. 128, 134 (1954); Olmstead v. United States, 277 U.S. 438, 466-68 (1927); cf. Kansas City S. Ry. v. Leslie, 112 Ark. 305, 329, 167 S.W. 83, 92 (1914), rev'd on other grounds, 238 U.S. 599 (1915).

$1 " 344$ U.S. at 203.

19355 U.S. 96 (1957).

${ }^{20} I d$. at 100; cf. Elkins v. United States, 364 U.S. 206 (1960). But cf. Ferguson v. United States, 307 F.2d 787 (10th Cir. 1962).

${ }^{21} 388$ U.S. 41 (1967).

${ }^{22} 389$ U.S. 347 (1967).
} 
unconstitutional a New York statute authorizing eavesdropping or wiretapping under court order on the grounds that the statute was overly broad, the Court setting forth specific guidelines for a valid "seizure" of words. ${ }^{23}$ While not arising under section 605, Berger was the first case finding evidence obtained by eavesdropping in violation of the fourth amendment to be inadmissible in state courts. The $\mathrm{Katz}$ case emphasized that the fourth amendment primarily guarantees the privacy of people rather than places and indicated that with proper limitations a court order could be granted for eavesdropping which would not be constitutionally defective. ${ }^{24}$

In Lee the Court did not reach the constitutional questions considered in Berger and $\mathrm{Katz},{ }^{25}$ but rather treated the question as one of statutory construction involving interpretation of congressional intent. While noting that persons using party lines should be aware that they may be overheard, the Court found continuous and deliberate electronic surveillance of the line to be an "interception" of communications within the meaning of section 605.26 Effectively overruling the Schwartz $v$. Texas position that federally proscribed interceptions were admissible in state prosecutions, the Court excluded the recorded conversations of Lee from the Florida proceeding. The holding was based upon both Mapp v. Ohio, ${ }^{27}$ which imposed an exclusionary rule on the states to ensure that state evidentiary rules did not interfere with federal rights, and on the proposition of Elkins $v$. United States ${ }^{28}$ that no court, state or federal, should take part in a violation of federal law. Thus the Court extended section 605 to the states, not only to determine that the conduct of the officers was proscribed, but also to disallow use of the intercepted conversations in a state criminal proceeding. The Court emphasized that the only effective way to achieve adherence to federal law is to remove the incentive to violate it by mandatory exclusion of the fruits of the violation. ${ }^{29}$ The dissenters in Lee, however, viewed Mapp $v$.

${ }^{23} 388$ U.S. at $44,53-60$.

24389 U.S. at 351, 354. See also Warden v. Hayden, 387 U.S. 294, 300-10 (1967).

$2 s 392$ U.S. at 379 n.2.

${ }^{26}$ Id. at 381-82; cf. Rathbun v. United States, 355 U.S. 107 (1957); United States v. Dote, 371 F.2d 176, 179-80 (7th Cir. 1966).

${ }^{27} 367$ U.S. 643 (1961).

2* 364 U.S. 206 (1960). See also Lopez v. United States, 373 U.S. 427, 437-40 (1963); On Lee v. United States, 343 U.S. 747, 754-56 (1952).

29392 U.S. at 386-87; accord, Mapp v. Ohio, 367 U.S. 643, 656 (1961); cf. Pugach v. Dollinger, 277 F.2d 739 (2d Cir. 1960), aff d per curiam, 365 U.S. 458 (1961). But cf. United 
Ohio as requiring exclusion only for constitutional violations, and therefore not applicable in considering the Federal Communications Act. They asserted that in dealing with a federal statute's application to the states, a definite statement of intent to exclude evidence from state proceedings should be made by Congress. ${ }^{30}$

The Crime Control Act establishes congressional policy in many areas which were previously covered only by Supreme Court interpretation, thus clarifying the extent to which Congress desires to limit wiretapping. Primary regulation of wiretapping is placed in a new chapter of the U.S. Code, ${ }^{31}$ while section 605 , as rewritten, is principally concerned with communications personnel. ${ }^{32}$ Wiretapping is absolutely prohibited except in specific cases. ${ }^{33}$ Interception alone is enough to constitute a violation, and interception is defined to include aural acquisition of the contents of any wire or oral communication, ${ }^{3+}$ apparently indicating congressional intent to adhere to the Supreme Court's pronouncement in Katz that the privacy of the communication itself must be protected, not merely the means of communication. ${ }^{35}$ The Act provides that communications intercepted in violation of the new chapter are inadmissible in evidence in any federal or state criminal, civil or administrative proceeding. ${ }^{36}$ Since the new section 605 is directed solely at the conduct of communications personnel, rather than wiretapping in general, Lee will probably be the last important case to interpret the section, and litigation in this area should be greatly reduced.

The Crime Control Act authorizes wiretapping in several specific instances. The President may allow it for national security; communications personnel may make interceptions incident to the proper performance of their duties which would otherwise be proscribed; and law enforcement officials may legally tap if they obtain a court order. ${ }^{37}$ The procedural steps written into the law

States v. Gris, 247 F.2d 860 (2d Cir. 1957); United States v. Gruber, 123 F.2d 307 (2d Cir. 1941).

${ }^{30} 392$ U.S. at 387-88 (Black, J., \& Harlan, J., dissenting respectively). In fact, Congressional intent to exclude illegally obtained evidence was to some degree manifested in consideration of the Crime Control Act before Lee was argued. See 1968 U.S. CODE CONG. \& AD. NEwS 1971.

" 82 Stat. (1968 U.S. CODE CONG. \& AD. NEWS at 1512-25).

327 U.S.C. $\$ 605$ (1968 U.S. CODE CONG. \& AD. NEWS 1525-26).

${ }^{33} 18$ U.S.C. $\$ \$ 2511,2516$ (1968 U.S. CODE CONG. \& AD. NEWS 1513, 1517).

${ }^{4} 18$ U.S.C. $\$ \S 2511,2510(4)$ (1968 U.S. Cọde Cong. \& AD. News 1513, 1512); cf. Silverman v. United States, 365 U.S. 505, 507-08 (1961).

${ }^{35}$ See Katz v. United States, 389 U.S. 347, $351-52$ (1967).

36 18 U.S.C. $\$ 2515$ (1968 U.S. CODE CONG. \& AD. NEWS 1517).

${ }^{37} 18$ U.S.C. $\$ \S 2511,2516-18$ (1968 U.S. CODE CONG. \& AD. NEWS 1513-14, 1517-24). 
attempt to follow the guidelines set forth in Berger and Katz for constitutionally acceptable wiretapping. ${ }^{38}$ Thus, an official must apply to a judge, stating the place, facilities and type of communications desired to be tapped, as well as the identity of the person and the type of offense of which he is suspected. Upon a determination of probable cause and necessity, a judge may issue an order specifying who will do the interception, the location and type of facilities for which the interception is authorized, whether or not the interception is to cease when the desired communication is first obtained, and the time limit which may be no longer than thirty days. After the end of the time period, notice must be given to the persons named in the order informing them of the order and whether or not communications were intercepted. ${ }^{39}$

The new code sections prohibiting interception and proscribing admission in evidence of communications intercepted in violation of the chapter ${ }^{40}$ indicate that the desires of Congress and the rulings of the Supreme Court are in harmony in these areas. The deeision in Lee, extending the exclusionary rule to the states, demonstrates that the majority of the Court either correctly divined Congress' intent in the original section 605 or anticipated the new provisions. The sections which authorize interception under court order ${ }^{41}$ however, may not yet reflect the strict drafting necessary to comply with the Berger guidelines. Berger stressed that indiscriminate or general eavesdropping could not be allowed ${ }^{42}$ and in $K a t z^{43}$ and Osborn $v$. United States, ${ }^{44}$ the Court emphasized that no innocent conversations were overheard. However, the Crime Control Act would allow interception of all conversations on particular facilities for so long as a month ${ }^{45}$ thus perhaps permitting a general search. A constitutional problem may also arise from the provision that the required notice need not state exactly what was intercepted ${ }^{46}$ since Berger criticized

\footnotetext{
${ }^{38}$ See S. ReP. No. 1097, 90th Cong., 2d Sess. 97-105 (1968).

${ }^{39} 18$ U.S.C. $\$ 2518$ (1968 U.S. CODE CONG. \& AD. NEWS 1519-23).

${ }^{40} 18$ U.S.C. $\$ \S 2511$, 2515 (1968 U.S. CODE CONG. \& Ad. NEws 1513, 1517).

"18 U.S.C. $\$ \S 2516-18$ (1968 U.S. CODE CoNG. \& AD. News 1517-24).

${ }^{42} 388$ U.S. at 57-59; cf. Marron v. United States, 275 U.S. 192, 196 (1927). See notes $21 \& 38$ supra.

${ }^{43} 389$ U.S. at 354 . See notes 22 \& 38 supra.

4385 U.S. 323, 329-30 (1966).

is 18 U.S.C. $\$ 2518$ (1968 U.S. Code Cong. \& Ad. News 1519).

${ }^{4} \mathrm{Id}$.
} 
the New York statute for failing to require a return ${ }^{47}$ and Katz condemned the government's activity because the agents were not required to "notify the authorizing magistrate in detail of all that had been seized." 48 Another possible problem exists because the new chapter defines an "aggrieved person" as a party to an intercepted communication or one against whom the interception was directed ${ }^{49}$ and allows only such a person to move to suppress the communication if improperly seized. ${ }^{50}$ Thus, a third person may be adversely affected or incriminated by unlawfully seized communications and yet have no standing to object, ${ }^{51}$ even though the chapter plainly states that no such communication will be admissible. Since Congress intends to severely limit wiretapping, the exclusion of evidence seized improperly is a necessary method of achieving this end. If police are able to use improperly intercepted communications against persons who have no standing to object, the Court may follow the position set forth in Elkins ${ }^{52}$ and reaffirmed in $L e e^{53}$ that a procedure which subverts the clear intent of Congress will not be allowed, extending this principle to the standing area. The Crime Control Act and the Lee decision indicate that Congress and the Supreme Court are on convergent courses concerning privacy of communication. Although constitutional obstacles to authorized wiretapping have not been completely resolved, these recent developments augur well for a definite and salutary treatment of the controversial wiretap subject.

\footnotetext{
4388 U.S. at 60.

4389 U.S. at 356. See also New York Eavesdropping Warrants Law, 1968 McKInNeY's Session law News, ch. 546; A Ba Project on Minimum Standards for Criminal Justice, Standards Relating to Electronic SurVeillanCE 206-36 (1968) (tentative draft).

418 U.S.C. $\$ 2510$ (11) (1968 U.S. CODE CONG. \& AD. News 1513).

3018 U.S.C. $\$ 2518(10)$ (a) (1968 U.S. Code Cong. \& AD. News 1523); cf. United States v. Tane, 329 F.2d 848, 852-53 (2d Cir. 1964).

"See Goldstein v. United States, 316 U.S. 114, 122 (1941); cf. Wong Sun v. United States, 371 U.S. 471, 491-92 (1963). But see Jones v. United States, 362 U.S. 257, 260-67 (1960). See also Mancusi v. De Forte, U.S. , (1968).

52364 U.S. at 222-24. See note 28 supra.

3392 U.S. at 385-86.
} 